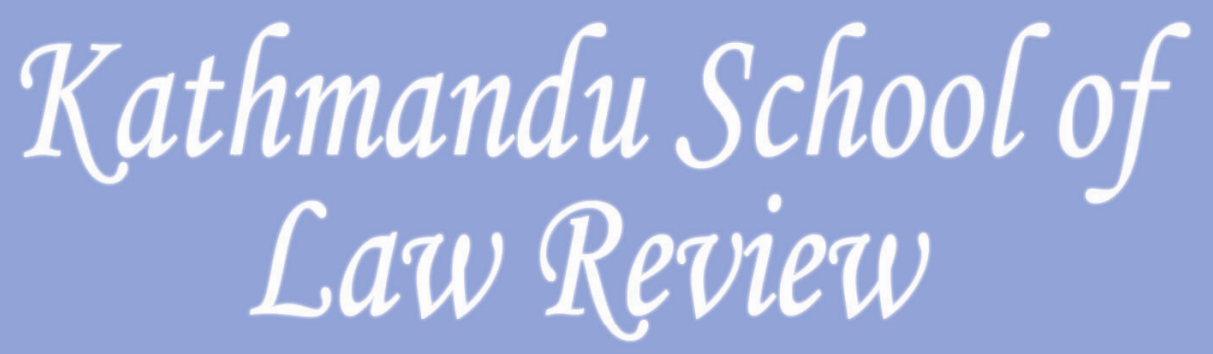

ISSN 2091-2110

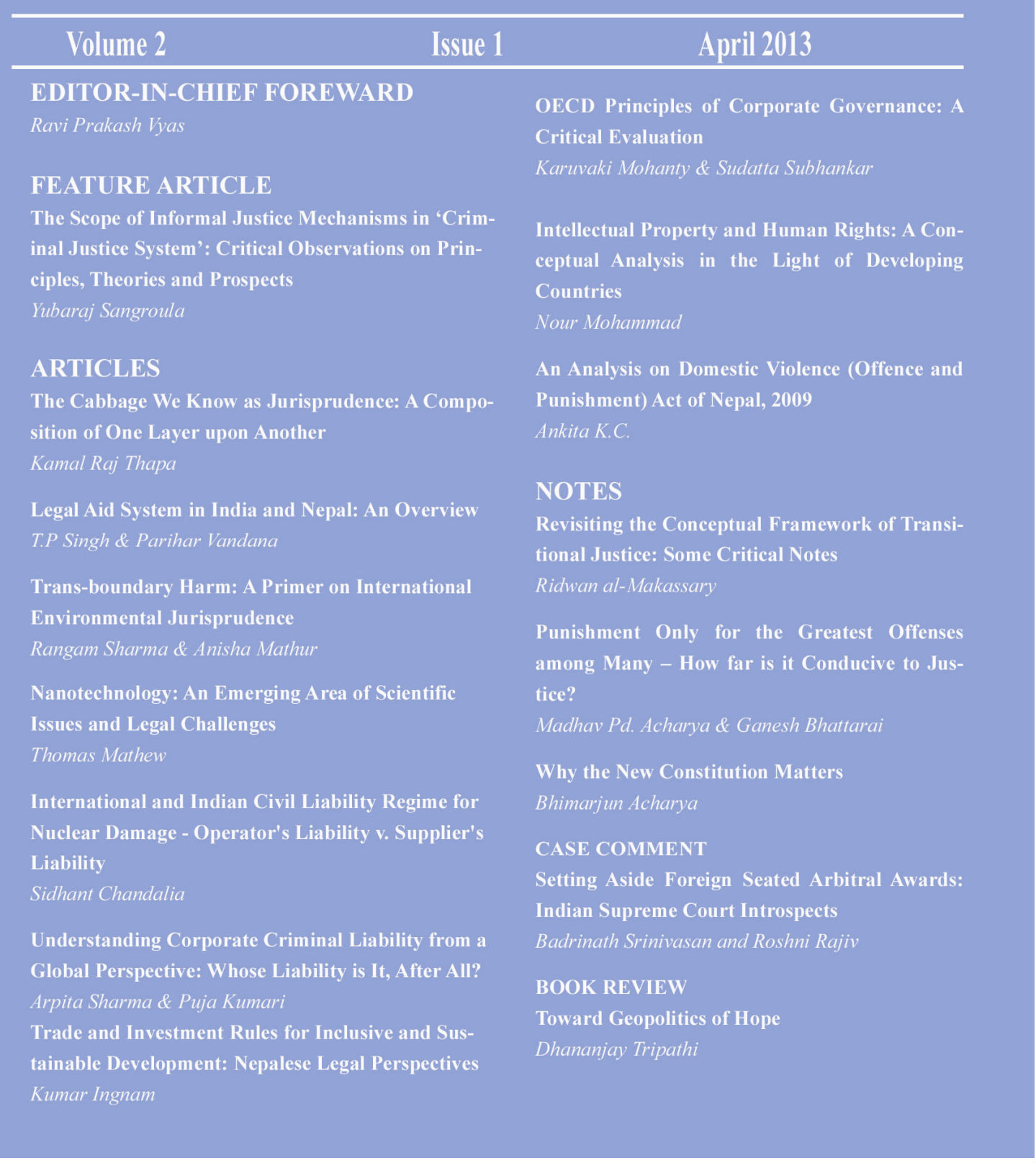




\title{
Legal Aid System in India and Nepal: An Overview
}

\author{
T.P Singh \& Parihar Vandana ${ }^{1}$
}

\begin{abstract}
Through this Article, an effort is made to understand the existing legal aid system of concerned countries, i.e. India and Nepal. The Constitution of India and the Interim Constitution of Nepal are the sources of social justice and the aim and objective of this Article is to draw focus on them. Both the countries have changed their domestic law to harmonize with international covenants. The co-relation between human rights and the fundamental rights is necessary to a proper social justice. This article assesses the legal aid system of India and Nepal. Legal Aid Act 1997 of Nepal and Legal Service Authority Act 1987of India are functioning in the forefront but the soul lies in the Constitution of the respective countries. The article presents comparative legal view on the systems. Likewise, the article attempts to find out the strength and weakness of the Legal Aid System and solutions to overcome the shortcoming of the system.
\end{abstract}

\section{Introduction}

This research article is an attempt to investigate the Legal Aid System in India and Nepal. Both are developing neighbouring countries but different in context to their geographical and demographic conditions. Nepal has seen rapid political changes during the last two decades. Before 1989, Nepal had a partyless Panchayat system in existence. In 1989, the Jana Andolan forced King to accept and pave way for constitutional reforms and establish multiparty parliament that took seat in May 1991. April 2006 brought a change in the system of governance in Nepal whereby it was declared as a secular state. It was then the Interim Constitution was promulgated and came in force in 15 January, 2007. Legislature, executive and judiciary are three functioning organ defined by the Interim Constitution.

India obtained freedom on 15August 1947 from being a British colony. Officially called Republic of India, Bharat Ganrajya, is a South Asian country and the most populous democracy in the world. It is a parliamentary republic with a multi-party system and governed under the supreme legal document of the state, i.e. the Constitution of India, which came into effect on 26 January 1950. Legislature, executive and judiciary are three functioning organ defined by the Constitution.

T.P. Singh is Professor of Law and Principal at Rajiv Gandhi College, Bhopal (India) and Parihar Vandana is an LLM (IV SEM) student at Rajiv Gandhi Law College, Bhopal (India). 


\section{Analysis of Motto of Legal Aid}

If we just go through the preambles of the Constitution of the India and the Nepal, they give us a clear understanding of the objectives and goals of legal aid programmes. Preamble of the Indian Constitution explains three type of justice, which is social, economic and political. In the true sense, persons could get freedom if their rights are properly recognized by the procedure of law. India got freedom after two hundred years of British rule and became the largest democracy of the world in 1947. The Constitution of India came into force in 1950, but it was in the year 1976 that a new article 39-A was added in Chapter IV containing the Directive Principles of State Policy by the Constitutional Amendment $\mathrm{Act}^{2}$ which seeks to provide equal justice and free legal aid to those who are deprived of the same due to economic disabilities. Keeping in view this legal philosophy which is amply reflected in the Part III and IV of the Indian Constitution, the Apex Court has recognised that legal aid and assistance to a poor or indigent accused who is arrested and put in jeopardy of his life or personal liberty, is the constitutional imperative mandated not only by Article 39-A but also by Article 14 and $21^{3}$. Principles of Natural Justice form the very basis of the rule of law. Here, both of the parties of the matter are the soul of natural justice. All the above mentioned fundamental right are based on the well settled principle of natural justice.

Like the Indian constitution, the preamble of the Interim Constitution of Nepal 2007 does not define the word justice but access to justice is present in the words of fundamental right and human rights aspirations. It is the duty of State to ensure the rights of person. Government of Nepal and educational institutes are involved in this field. The ways are different in both the countries but the motto is absolutely the same.

\section{International Perspective of Legal Aid}

In the 1960s particularly in the United States, the world saw a broader approach developed with respect to the role of legal aid and services in general. The US' President Johnson's War on Poverty has the objective of elimination of poverty, rather than extension of existing legal services to non-paying clients. The European Conference of Minister issued a declaration on legal aid in the late 1970s which considered the right of access to justice an essential feature of any democratic society and firmly stated that legal aid no longer could be considered a charity, but an obligation of the community as a whole.

The United Nations International Covenant on Civil and Political Rights (ICCPR) ${ }^{4}$, article 14(3) (d) principally requires an accused offender 'to have legal assistance assigned to him, in any case where the interests of justice so require, and without payment by him in any case if he does not have sufficient means to pay for it'. The right to free legal counsel is

The Constitution 42 ${ }^{\text {nd }}$ (Amendment ) Act 1976.

Ellanath Sahu v. State of Orrisa (1990) CLT 358.

ICCPR (adopted 16 December 1966, entered into force 23 March 1976) 999 UNTS171. 
therefore rooted in the idea of equality. This is not binding upon the States, but has been accepted by a large number of States and is considered to have moral force. At the present this treaty provision has become part and parcel of national law through incorporation by new legislation or amendment of legislation. Both India and Nepal have become a part of the international treaty and accepted these provisions related to legal assistance that resound in the Fundamental rights and Directive principles in both the countries.

\section{Legal Aid under Codified Law in India}

Before going through the matters related to the codified law of India, it is necessary to take a glimpse of Article39-A of the Constitution, which provides for equal justice and free legal aid.

Article 39-A reads that:

The State shall secure that the operation of the legal system promotes justice, on a basis of equal opportunity, and shall, in particular, provides free legal-aid, by suitable legislation or schemes or in any other way, to ensure that opportunities for securing justice are not denied to any citizen by reason of economics or other disabilities.

On the other hand, Order XXXIII, rule 18 of the Civil Procedure Code 1908 provides that the State and Central government may make supplementary provision as it thinks fit for providing free legal aid services to those who have been permitted to sue as an indigent person. The Criminal Procedure Code 1973 section 304 provides legal aid to accused at state's expense in certain cases, when trial is conducted by Court of Session and High Court many with the previous approval of the State government, make rule for providing legal help.

\section{Developmental Phase of Legal Aid in India and Nepal}

After Independence, in 1952 the government of India started addressing the question of legal aid for the poor in various conferences of Law Ministers and Law Commission. In 1960, some guidelines were drawn by the government for the legal aid schemes. Later, legal aid schemes were conducted through legal aid boards, societies and law department in various states in the country. In 1980, the National Commission was constituted under the chairmanship Honourable Justice P.N. Bhagwati who supervised legal aid programmes throughout the country and the committee came to be known as CILAS (Committee for Implementing Legal Aid Scheme).

The Legal Services Authorities Act 1987 has made remarkable changes in the field of legal services in India. With the help of this Act, denial of justice to any citizen due to the reason of economic or other disability is successfully avoided. Legal Service Authorities provide free and competent legal service to the weaker section of society. Lok Adalats are organised 
to secure that the operation of the legal system promotes justice on the basis of equal opportunity. In the present scenario, Lok Adalats are successfully conducted in India and provide supplementary forum to the litigants for conciliatory settlements of their dispute. This act was finally enforced on 9 November 1995, after certain amendments which were introduced by the Amendment Act 1994.

A nationwide network has been envisaged under this Act for providing legal aid and assistance. The National Service Authority is the apex body constituted to lay down the policies and principles in order to avail legal services. The provisions of this Act attempt to frame most effective economical scheme for legal services, to disburse funds and grants to the State Legal Services Authority and NGOs' for the implementation of free legal aid schemes and programmes. The State Legal Services Authority is headed by the Chief Justice of the respective high courts, which conduct Lok Adalats in the concerned State.

District Legal Services Authority Act is constituted in each district to implement legal aid programmes and schemes. The district judge is its ex-officio chairman, whereas the Taluk Legal Services Committees are constituted for each Taluk or Mandal, or the group of Taluks or Mandals in order to co-ordinate the activities of legal services in the Taluk and conduct Lok Adalats. Each Taluk legal service committee is headed by the civil judge and is operated within the jurisdiction of the committee.

In India, right to get legal aid starts from the point when the accused is arrested. If the accused is not aware of his legal aid right then it is the duty of the Magistrate to provide necessary information about the right and it is the duty of the police to inform the nearest legal aid committee about the arrested person, seeking legal aid for the first time and this procedure goes on whenever the person is brought in for questioning.

Sources of legal aid in the Nepal are court, legal aid committee, the Bar and NGOs'. The first source of legal aid is the court. The system of legal aid through a stipendiary lawyer was created by the supreme court of Nepal in 1958 by an administrative decision. The provisions related to the stipendiary lawyer are incorporated in the rules of various courts, for example in the Supreme Court Rules 1992, Appellate Court Rules 1991 and District Court Rules 1995. Rules 111(A) of the Supreme Court Rules 1992 provides on legal aid.

One Supreme Court, 16 appellate courts and 75 district courts are included in the judicial arrangement in Nepal. In the each of these courts, one stipendiary lawyer is appointed by the court for rendering free legal aid to the needy person for the period of one year. However, in the supreme court, there are two stipendiary lawyers. The stipendiary lawyer is a practicing private Lawyer; he/she can do their practice as well as work with officers of court and provide legal aid services. The court provides legal aid at the stage of hearing of a case by a bench. Legal Aid is not applicable to some other activities like preparation of case, collection of evidence, assessment and examination of evidence. Irony is that a Vaitanik Wakil (stipendiary Lawyer) presents before the court and pleads the case but often, 
the client and lawyer do not meet each other. Currently the courts are providing legal aid in both the criminal and civil case.

In India there are no provisions to appoint such kind of lawyer, but it is the duty of the State under the provisions of codified law and Constitution to provide free legal aid as required by needy indigent person.

Some important strengths of the legal aid provided by the courts are its sustainability, accessibility, institutionalised system and coverage of all 75 districts of Nepal. Despite these strengths, there are few serious weakness present in the legal aid provided by the courts, like involvement of efficient professional lawyer in the legal aid programme. There is a very formal relation between court and the stipendiary lawyer and the monitoring of court over the work of legal aid lawyer is very poor. Condition is the same in India. There is also a need of involvement of efficient lawyers in free legal aid service but due to lack of enthusiasm, lawyer are less inclined towards social service and advocacy has become a money-extracting job now.

Another source of legal aid in Nepal is the State. The Central and District Legal Aid Committees are working under the Legal Aid Act 1997.

One of the major strength of the legal aid provided by the government is its nature of sustainability and credibility. On the other side, there are some loopholes for example the Committee does not have its own lawyer, Bar assigns lawyers to provide legal aid and the lawyer is not paid well. Nominal fund is erected by the government for legal aid. The person getting legal aid has to obtain a recommendation letter from a local body such as VDC or municipality but some time it is difficult to get recommendation due to political biasness. Public Prosecutor is the head of District Legal Aid Committee who prosecutes against the detainees including who is provided with the legal aid on the behalf of the government. Researchers proved that the Public Prosecutors are very much ignorant about the significance of legal aid or they had negative attitude about it. Concept of reimbursement is also a weakness of the legal aid by government. If the person getting legal aid from the DLAC gets any property or financial benefit after the financial decision of a case, the person is required to reimburse the expenses of the legal aid incurred by the DLAC.

Nepal Bar Association (NBA) is another source of legal aid in the country, established in 1962. It is the one of the most active institutes in the area of legal aid. NBA is working with many project in the field of legal aid and is publishing booklets on the various issue to disseminate key information on law to the local community. NBA has also established a legal aid committee with a view to support. It strengthens legal aid projects and monitors the activities. It is the great implementer of the act with organised manner and having professional lawyers. One of the most acute weaknesses of the Bar is that it does not have 
its own funding for the legal aid. Currently the Bar is providing legal aid with the assistance of two major donors, i.e. the Norwegian Bar and the European Union.

Fourth source of legal aid is the civil society organisations, i.e. local and international NGOs. They provide more effective legal aid than other sources. Prompt and specialised services, strong networking and familiarity with the local needs and conditions are the strengths. The legal aid provided by the civil society organisation is donor-led ${ }^{5}$. They do not have their own funds. Lack of transparency in the financial matter is present. Legal aid provided by the NGOs is not sustainable because they work with projects which are time limited, i.e. as the project ends, the legal aid also ceases. Another weakness is that their geographical coverage is the least one among the legal aid providers. Lack of co-ordination and co-operation, urban area centrality and underutilization by the targeted groups are few other shortcomings. These shortcomings in the legal aid should be rooted out.

In India, many cases solved through free legal aid have made a history, like Hussainara Khatoon v. Home Secretary, State of Bihar ${ }^{6}$, M.H.Hoskot v. State of Maharashtra ${ }^{7}$, Indira Gandhi v. Raj Narin ${ }^{8}$ and State of Maharashtra v. Manubhai Pragaji Vashi ${ }^{9}$ to name a few. The Supreme Court of Nepal, in Yagya Murti Banjade v. Bagmati Special Court $2027^{10}$ ensured lawyer's representation in the criminal charges

The strength of Legal Aid system in Nepal is that educational institutes like school and universities are actively involved in spreading awareness about Legal Aid. In India, a vacuum is present in this field due to very nominal effort being made by the educational institutes. There is a need of great endeavour in the field of Legal Awareness by the educational institutes to achieve the goal.

\section{Conclusion and suggestions}

After assessing the system of legal aid in India and Nepal, the conclusions reached at are that the approach of legal aid is very significant but in order to achieve the goal or fulfill the complete requirement of free legal to the poor or needy person, some key problems have to be solved. A satisfactory system building, good coordination, great sustainability, effectiveness of service, credibility, easy access and optimal use by the targeted groups are the needs to fulfill the goal of legal aid system.

Client-Lawyer relation, interaction, meeting are important factors and cliental satisfaction is very necessary. Poor implementation of legal aid programme is a big drawback, it must take real shape. Improvements in the existing system, harmonization with the Bar, strong

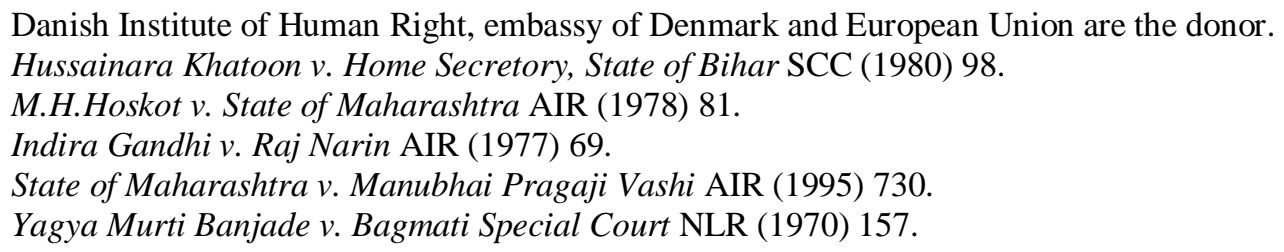


public defender system are necessary for success of legal aid system. It is suggested that active inclusion of law students and legal academician in the implementation of the legal aid programme be encouraged.

Common efforts should be taken in Nepal and India. Lack of unawareness must be eradicated, the lawyers in the panel should be experienced, the legal service which are given to the poor should be qualitative, adequate financial resources should be given in order to make the implementation of legal aid effective and awareness of scheme and programme should be enabled to guide the poor litigants about the issue of legal aid. Appreciation of NGOs', their expansion from urban to rural areas and their proper funding can promote effective functioning of the Legal Aid System in India, as well as in Nepal.

The important task before the legal service functionaries is to make the legal service law meaningful for those belonging to weaker and poor sections of the society. This can be done by educating the said section of the society. This underprivileged class has to be made to understand about the benefits of legal service law.

However, the legal aid system proves to be an effective and significant step taken by the government of Nepal and India, which efficiently satisfies the need to provide and spreads proper justice among the citizens of the respective states.

$* * * * * * * * * * * * * * * * * * *$ 